\title{
NOTE
}

\section{Lipid and lipid class content of the pelagic tunicate Oikopleura vanhoeffeni}

\author{
Don Deibel ${ }^{1}$, Joann F. Cavaletto ${ }^{2}$, Mike Riehl ${ }^{1}$, Wayne S. Gardner ${ }^{2}$ \\ 'Ocean Sciences Centre and Department of Biology, Memorial University, St. John's, Newioundland, Canada A1C 5S7 \\ ${ }^{2}$ Great Lakes Environmental Research Laboratory, National Oceanic and Atmospheric Administration, 2205 Commonwealth BIvd., Ann Arbor, \\ Michigan 48105, USA
}

ABSTRACT: Lipid biochemistry of pelagic tunicates is poorly known, despite the fact that the larvae of several flatfish species depend exclusively on oikopleurid appendicularians at time of first feeding. Microgravimetric analysis and thinlayer chromatography with flame ionization detection (TLCFID) were used to determine the total lipid content and lipid class composition of the pelagic tunicate Oikopleura vanhoeffeni. Our goal was to determine the dominant storage form of lipid in $O$. vanhoeffeni before and after the spring diatom bloom. Lipid levels and lipid class composition were measured for all 5 ontogenetic stages of $O$. vanhoeffeni, plus eggs. Levels ranged from 23 to $525 \mu \mathrm{g}$ ind. ${ }^{-1}$ over the entire life cycle, increasing exponentially with increasing body size and ontogenetic (i.e. maturity) stage. Regression analyses showed that $84 \%$ of the variation in the logarithm of total lipid content was explained by the logarithm of ontogenetic stage. Per unit dry weight, the mean ( \pm SE) lipid concentration was $5 \pm 0.3 \%$ before the bloom and $7.5 \pm 1.2 \%$ after the bloom. Lipid cläss composition provided scant evidence for energy storage by $O$. vanhoeffeni, with no wax esters before or after the spring bloom and moderate levels of triacylglycerols present in prebloom animals only. Individuals collected after the spring bloom were significantly smaller than those from before the bloom, suggesting that a spawning event had occurred sometime during the bloom. Predominant lipid classes before and after the bloom were phospholipids (65 to $90 \%$ of total lipid) and acetone-mobile polar lipids ( 4 to $24 \%$ ). Thus, although this appendicularian is a suspension feeder inhabiting very cold water, it does not store wax esters as do high-latitude copepods. Rather, $O$. vanhoeffeni has the lipid characteristics of a gelatinous, opportunistic colonist, i.e. that of an omnivore with the ability to direct ingested food energy into rapid somatic growth or gamete production.

Planktonic copepods living at high latitudes store energy seasonally in the form of deposit lipids, primarily triacylglycerols (TAG) and wax esters (WE) (Lee 1975, Falk-Petersen et al. 1987, Larson \& Harbison 1989, and references thereinj. These compounds provide energy for overwintering metabolism and spring egg production (Lee et al. 1972, Lee 1975, Gatten et al. 1980, Larson \& Harbison 1989, Smith 1990). In com- parison, energy storage by gelatinous zooplankton is poorly known. and studies have been limited to Carnivorous species (Joseph 1979, Clarke et al. 1987, Larson \& Harbison 1989). We have found no information on lipid levels in gelatinous suspension feeders such as the pelagic tunicates.

Oikopleura vanhoeffeni is a large, common, cold ocean pelagic tunicate with a pronounced seasonal cycle of abundance and spawning (Mahoney \& Buggeln 1983, Deibel 1988). It reproduces at least once each year, during the decline of the spring diatom bloom in April and May (Davis 1982, 1986). Individuals are hermaphroditic, producing several hundred eggs and copious sperm prior to spawning by rupture of the body wall. Large, pre-spawning tunicates are common in surface waters during mid-winter, when the concentration of particulate organic carbon (POC) and chlorophyll $a$ are at their annual minima (Deibel 1988).

Oikopleura vanhoeffeni is a generalist grazer, using a fine, mucous filter for feeding, ingesting particles from a wide size range including diatom chains (Deibel \& Turner 1985) and colloids (Flood et al. 1992). $O$. vanhoeffeni populations have a grazing impact in Newfoundland (Canada) waters equivalent to that of all the copepods combined (Knoechel \& Steel-Flynn 1989), and are a favored prey of larval and juvenile cod and flatfish (Shelbourne 1962, Gadomski \& Boehlert 1984, Keats et al. 1987, K. Frank pers comm.). Thus, this link in the food chain may represent a means by which energy flux from diatoms to fish is mediated.

Our goal was to determine the dominant storage form of lipid in Oikopleura vanhoeffeni collected before and after the spring diatom bloom. We have been able to document the lipid content of all 5 ontogenetic stages of $O$. vanhoeffeni, including eggs. These results may clarify the mechanism whereby 
O. vanhoeffeni is able to overwinter despite low food particle concentrations and may help to define its role in lipid and energy flux from phytoplankton to fish.

Methods. Oikopleura vanhoeffeni was collected individually into $500 \mathrm{ml}$ glass jars by SCUBA divers working in Logy Bay $\left(47^{\circ} 37^{\prime} \mathrm{N}, 52^{\circ} 40^{\prime} \mathrm{W}\right)$, insular Newfoundland, in February and May 1990 (water temperature -1.5 and $3.0^{\circ} \mathrm{C}$ respectively). Within 30 min of collection the individuals were transferred into filtered seawater (GF/C) for at least $60 \mathrm{~min}$ to permit gut evacuation. When the guts were colorless, each individual was prodded from its mucous 'house', then rinsed briefly in distilled water. The gonad was removed, and the remaining trunk measured to the nearest $10 \mu \mathrm{m}$ using a dissecting microscope with ocular micrometer. Each tunicate was assigned to 1 of 5 ontogenetic stages, after the categories introduced for O, labradoriensis by Shiga (1976). These are, (1) gonad absent, (2) small, undifferentiated testis present, (3) testis greater in height than in stage 2 , and divided into right and left halves, but both still less than the width of the trunk, (4) increase in height of gonad and first appearance of the ovary, and (5) gonad (testis + ovary) very large, wider and higher than the trunk.

Individuals were then placed in small, $2 \mathrm{ml}$ glass test tubes and dried under $\mathrm{N}_{2}$ at $55^{\circ} \mathrm{C}$ for at least $48 \mathrm{~h}$. This protocol was designed to destroy lipases while causing little or no oxidation of lipids. Small individuals were pooled (Table 1) to provide sufficient material for subsequent lipid analyses. It is not possible to determine accurately the dry weight of pelagic tunicates because of confounding problems with salt and chemically 'bound' water (Madin et al. 1981). The method of choice is to express weight as the mass of a particular element, such as nitrogen or carbon, determined by high-temperature combustion. In the present case, body length $(\mathrm{mm})$ was converted to carbon content $(\mu \mathrm{g})$ using the following power curve developed previously for O. vanhoeffeni (Deibel 1986).

$$
\begin{gathered}
\text { Carbon }=4.59 \text { Trunk }^{3.2} \\
\left(\mathrm{n}=25, \mathrm{r}^{2}=0.90, \mathrm{p}<0.001\right)
\end{gathered}
$$

Carbon content was then converted to an estimate of dry weight by multiplying by 12 , a factor derived for salps by Schneider (1989). After drying, the samples were shipped to the Great Lakes Environmental Research Laboratory, where they were stored frozen in

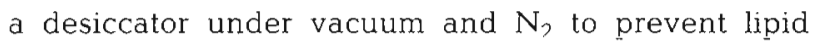
oxidation.

Total lipids were extracted with chloroform: methanol $(2: 1 \mathrm{v} / \mathrm{v})$, washed with an aqueous salt solution $(0.9 \% \mathrm{NaCl})$, and quantified gravimetrically using a micro-version (Gardner et al. 1985) of the method of Folch et al. (1957). A subsample (ca 5 to 10 Ml) of each lipid extract was sealed under nitrogen in a capillary tube and stored at $<0{ }^{\circ} \mathrm{C}$ for later determination of lipid classes by thin-layer chromatography with flame ionization detection (TLC-FID), (Parrish 1986, 1987, Parrish et al. 1988). The lipid extract was spotted directly onto silica-coated Chromarods-SIII (RSS Inc.).

Table 1. Oikopleura vanhoeffeni. Lipid content before and after the spring diatom bloom. Data is arranged both before and after the bloom in ascending order of ontogenetic stage. No. tunicates: number of individuals of similar body size pooled for the analysis; stage: a relative ranking ( 1 to 5) of the ontogenetic state of the specimens after the system of Shiga (1976; see 'Methods'

\begin{tabular}{|c|c|c|c|c|}
\hline No, tunicates & Stage & Trunk length (mm) & Total lipid (ug) & Lipid ( $\%$ of dry wt) \\
\hline \multicolumn{5}{|c|}{ February (pre-bloom) } \\
\hline 5 & 3 & 2.93 & 91 & 5.3 \\
\hline 1 & 4 & 4.38 & 278 & 4.5 \\
\hline 1 & 4 & 5.00 & 492 & 5.2 \\
\hline 1 & $4-5$ & 4.88 & 376 & 4.3 \\
\hline 1 & $4-5$ & 4.50 & 395 & 5.8 \\
\hline 1 & 5 & 3.00 & 525 & 28 \\
\hline \multicolumn{5}{|c|}{ May (post-bloom) } \\
\hline 5 & 1 & 1.44 & 26 & 15 \\
\hline 3 & 2 & 2.38 & 23 & 2.6 \\
\hline 3 & 2 & 2.40 & 53 & 5.8 \\
\hline 3 & 2 & 2.25 & 41 & 5.5 \\
\hline 3 & 2 & 2.38 & 57 & 6.5 \\
\hline 3 & 2 & 2.53 & 77 & 7.1 \\
\hline 3 & 3 & 2.58 & 88 & 7.7 \\
\hline 1 & 4 & 2.90 & 191 & 11 \\
\hline 1 & 4 & 3.10 & 269 & 13 \\
\hline
\end{tabular}
for explanation) 
Lipid classes were separated by sequentially developing the rods in increasingly polar solvent systems (Parrish 1986, 1987). After solvent development, rods were scanned with an Iatroscan Mark IV (Iatron Labs, Tokyo, Japan) connected to a Hewlett-Packard 3392A. integrator A mixed lipid standard, containing 1 compound from each of the following lipid classes: hydrocarbon, sterol ester, triacylglycerol, free fatty acid, alcohol (aliphatic), sterol (alicyclic alcohol), and phospholipid, was used for TLC-FID calibration and quantification. Calibration curves were determined over a range of 0.15 to $30 \mu \mathrm{g}$ for each standard compound.

All mean values reported in the text are $\pm 1 \mathrm{SE}$ unless indicated otherwise. All statistical tests of differences between mean values are $t$-tests unless indicated otherwise. All proportions were transformed using the arcsin before hypothesis testing.

Results. The individuals analyzed in this study ranged in trunk length from 1.44 to $6.25 \mathrm{~mm}(\overline{\mathrm{x}} \pm \mathrm{SD}=$ $3.38 \pm 1.26 \mathrm{~mm}, \mathrm{n}=18$ ). Mean body size was significantly greater $(p<0.01)$ before the spring bloom $(\bar{x}=$ $4.45 \pm 0.38 \mathrm{~mm}, \mathrm{n}=8$ ) than after the bloom $(\overline{\mathrm{x}}=$ $2.53 \pm 0.16 \mathrm{~mm}, \mathrm{n}=10$ ). This result is consistent with the occurrence of a spawning event sometime during the bloom, in April or early May. This difference in body size was reflected in the total lipid content, with a mean of $359 \pm 65 \mu \mathrm{g}$ ind. ${ }^{-1}$ before the bloom $(n=6)$, and a significantly lower mean $(\mathrm{p}<0.001)$ of $92 \pm 28 \mu \mathrm{g}$ ind. $^{-1}$ after the bloom ( $\mathrm{n}=9$, Table $1 ; 3$ samples lost during analysis). Considering all data from before and after the bloom, total lipid content increased exponentially with increasing body size (Fig. 1a) and ontogenetic stage (Fig. 1b). Regression analyses indicated that ontogenetic stage was a better predictor of lipid content than was body size, accounting for $84 \%$ of the total variability (Fig. 1b). The slight overlap in body size of individuals collected before vs after the bloom prohibited meaningful statistical comparison of slopes and intercepts for the 2 sampling dates shown in Fig. 1a, b. After converting body length to an estimate of dry weight (see 'Methods'), lipid content of ontogenetic stages 2 to 4 ranged from 4.3 to $5.8 \%$ of dry weight before the bloom ( $\bar{x}=5.0 \pm 0.3 \%, n=5)$ and 2.6 to $13 \%$ after the bloom $(\bar{x}=7.5 \pm 1.2 \%, n=8$; Table 1$)$.

The lipid class data provided scant evidence of energy storage in Oikopleura vanhoeffeni (Fig. 2). Sterol and wax esters (WE), methyl esters (ME) and diglycerides (DIG) were not detectable before or after the bloom. The predominant classes were acetonemobile polar lipids (AMPL, which may include chlorophylls, glycolipids and monoacylglycerols; range 4 to $24 \%$ of total lipid) and phospholipids (PL, range 65 to $90 \%$ of total lipids). There were no triacylglycerols (TAG) found in individuals collected after the bloom, and no hydrocarbons (HC) or alcohols (ALC) in those collected before the bloom. Free fatty acids (FFA) and sterols (ST) were found in limited quantities in individuals collected before and after the bloom.

Combining lipid class data from before and after the bloom revealed little trend in \% composition with increasing body size (Fig. 3a to c). This result indicates that although lipid levels increased with increasing body size (Fig. 1a), lipid class composition was relatively independent of body size. Simple linear regression analyses showed that only TAG had a significant relationship with body size (the slope was significantly different from 0 at $\mathrm{p}<0.05$ ). However, between indi-
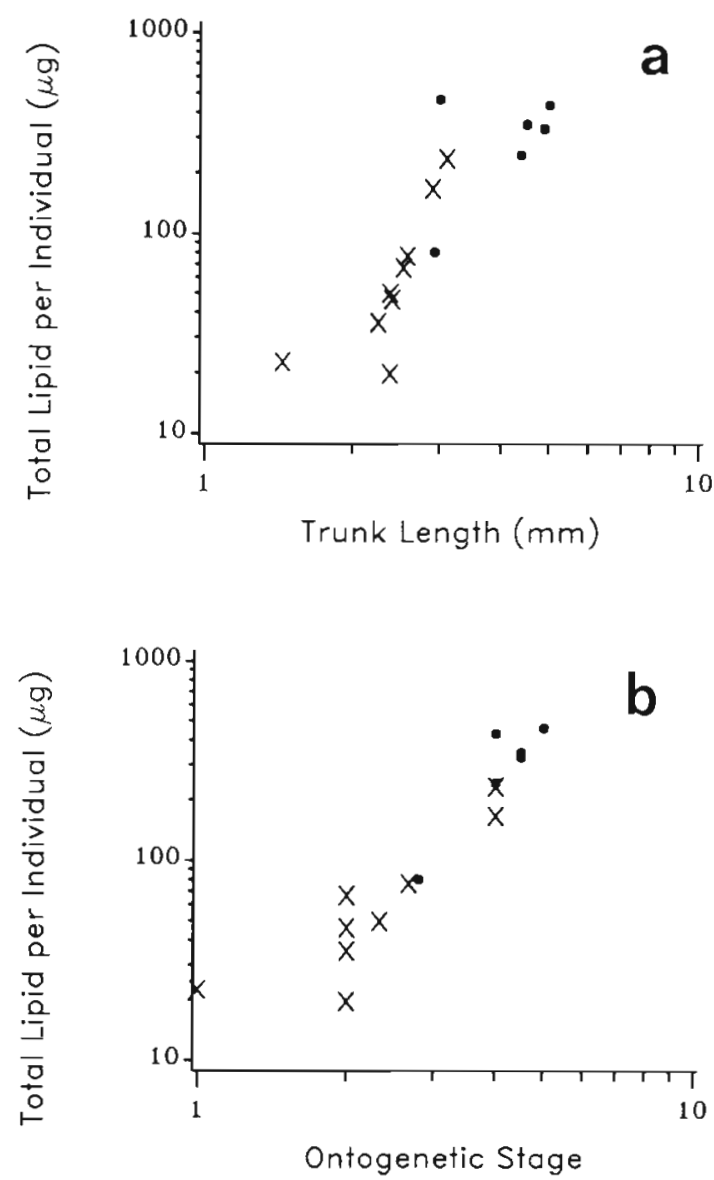

Fig. 1 Oikopleura vanhoeffeni. Log-log plot of total lipid content ( $\mathrm{kg}$ ind. ${ }^{-1}$ ) vs (a) body size (i.e. trunk length in $\mathrm{mm}$ ) and (b) ontogenic stage, $(\bullet)$ before $(n=6)$ and $(x)$ after $(n=9)$ the spring diatom bloom. Ontogenetic stage ranking ( 1 to 5 ) is after the system developed by Shiga (1976; see 'Methods'). A stage of 4.5 represents 2 individuals that were judged to be intermediate between stages 4 and 5 . All other fractional values of maturity stage represent the mean stage of a pool of individuals of similar length (see Table 1 for the number of individuals pooled in each case). The equation for the power curve relationships are: (a) lipid content $=6.7 \times$ trunk length ${ }^{2.69 \pm 0.46}\left(\mathrm{n}=15\right.$, adjusted $\left.\mathrm{r}^{2}=0.70\right)$, with slope significantly different from zero $(F=34.4, \mathrm{p}<0.001)$; and (b) lipid content $=12.0 \times$ stage $^{222 \pm 0.26}\left(n=15\right.$, adjusted $\left.r^{2}=0.84\right)$, with slope significantly different from zero $(F=75.2$, $\mathrm{p}<0.001)$ 


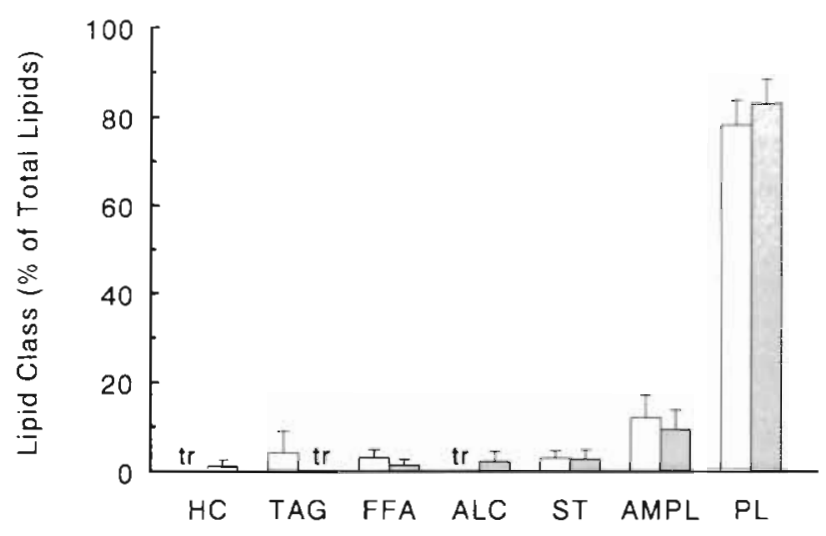

Fig. 2. Oikopleura vanhoeffeni. Lipid class composition ( $\%$ of total lipid $+2 \mathrm{SE}$ ) (open bars) before and (shaded bars) after the spring diatom increase. ( $\mathrm{n}=6$ for all before bloom samples, and $\mathrm{n}=8$ for all samples taken after the bloom.) $\mathrm{HC}$ : hydrocarbons; TAG: triacylglycerols; FFA: free fatty acids; ALC: dicohols; ST: sterols; AMPL: acetone-mobile polar lipids; PL: phospholipids; tr: levels not quantifiable. Sterol esters, wax esters, methyl esters and diglycerides were never found in any of our samples

vidual variability was high, since TAG's were found in only 4 of the 6 specimens collected before the bloom (Fig. 3c). In addition, there were no statistically significant relationships between the proportion of any of the lipid classes and ontogenetic stage (data not shown, slopes not different from 0 at $p>0.15$ ). A single sample of Oikopleura vanhoeffeni eggs that was examined presented a lipid class signature similar to the above pattern, containing predominantly PL (85\%), with lesser content of ST $(7 \%)$ and AMPL $(6 \%)$.

Discussion. The exponential increase in total lipid content with increasing body size and ontogenetic stage (Fig. 1a, b) and the predominance of PL (Fig. 2), both suggest that the lipid biochemistry of Oikopleura vanhoeffeni is dominated by the accretion of somatic tissue during growth. The presence of a high proportion of PL indicates investment in cell membranes, and is similar to the lipid class composition of deepliving sea anemones (PL is 70 to $75 \%$ of total lipids; Joseph 1979), ctenophores (PL is 67 to $70 \%$; Lee 1974 , Morris et al. 1983) and chaetognaths (PL is 63 to $78 \%$; Lee 1975, Falk-Petersen et al. 1987). Although not examined here, it is possible that polyunsaturated fatty acids (PUFA's) within the PL of oikopleurid cell membranes may help to maintain membrane fluidity at subzero water temperatures, as is true for the giant scallop Placopecten magellanicus living in the same waters as O. vanhoeffeni (Napolitano et al. 1992).

Because Oikopleura vanhoeffeni is large, it may serve as a significant source of dietary lipid and other nutrients for predators, including larval and juvenile fish (Shelbourne 1962, Gadomski \& Boehlert 1984,
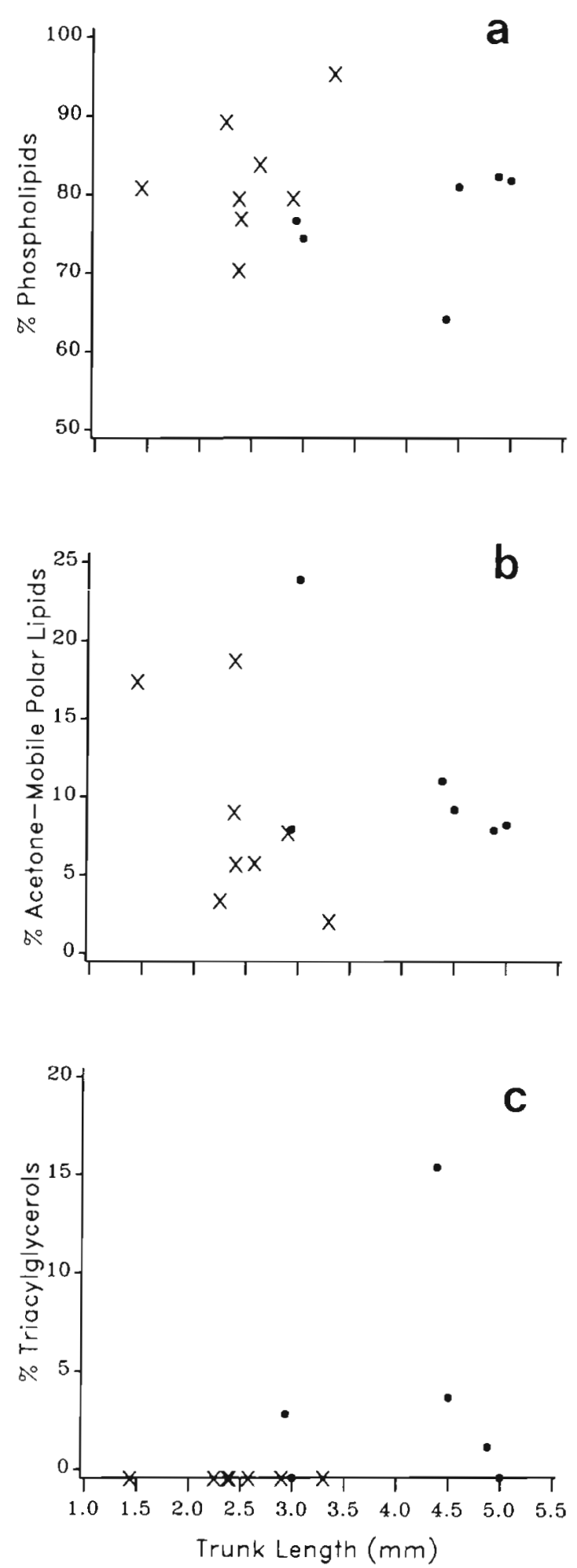

Fig. 3. Oikopleura vanhoeffeni. Lipid class composition (\% of total lipid) vs body size (i.e. trunk length in $\mathrm{mm}$ ) ( $\bullet$ ) before and $(x)$ after the spring diatom bloom. Only \% TAG shows a significant positive relationship with trunk length $(\mathrm{n}=14$, adjusted $\left.r^{2}=0.23\right)$. The slope is significantly different from 0 $(F=4.8, p<0.05)$. All other slopes are not different from 0 $(p>0.15)$. Note the different scaling of the $y$-axes 
Keats et al. 1987). O, vanhoeffeni has a lipid content ( $\overline{\mathrm{X}}$ $\pm \mathrm{SD}=199 \pm 177 \mu \mathrm{g}$, range 23 to $525 \mu \mathrm{g}$; Table 1) equivalent to ca 6 , stage 5 copepodites of Calanus finmarchicus (ca $30 \mu \mathrm{g}$ ind. ${ }^{-1}$, Kattner \& Krause 1987), the predominant, large copepod in Newfoundland waters. Data from Conception Bay, Newfoundland ( $\mathrm{K}$. Frank pers. comm.), indicate that the guts of juvenile Atlantic cod Gadus morhua, ca $90 \mathrm{~mm}$ long, at times may contain the remains of 170 oikopleurids. This is equivalent to a minimum of $3.9 \mathrm{mg}$ of lipid larva ${ }^{-1}$ if only the smallest oikopleurids are being eaten, or 34 $\mathrm{mg}$ of lipid larva ${ }^{-1}$ if oikopleurids of average size are being eaten.

Most of the existing information on lipids in gelatinous zooplankton concerns 'carnivorous' species. Arctic medusae and ctenophores have a mean lipid content of $8 \%$ of dry weight (range of 1.5 to $22 \%$, Clarke et al. 1987, Larson \& Harbison 1989). These values are much lower than the lipid content of suspension-feeding copepods in these waters ( 8 to $64 \%$, Lee 1975, Kattner \& Krause 1987, Tande \& Henderson 1988, Hargrave et al. 1989, Smith 1990). Thus, the metabolism of oikopleurid tunicates appears to be more similar to that of gelatinous predators than to copepods. Possible reasons for this difference are that oikopleurids may not depend on a seasonally-pulsed food supply as do copepods, or that these tunicates may store energy in other more useable forms, e.g. glycogen. As far as we know, no one has examined the carbohydrate metabolism of a pelagic tunicate. Alternatively, pelagic tunicates may simply grow or produce gametes in response to pulses in food supply (Lee 1974) and shrink when food is scarce (Morris et al. 1983). This strategy is typical of opportunistic or 'colonist' species.

The lipid class composition of Oikopleura vanhoeffeni provides scant evidence for energy storage by overwintering populations or by populations responding to the spring diatom bloom. The absence of WE in specimens collected before or after the bloom is consistent with published information on sponges, ctenophores and chaetognaths (Joseph 1979, Morris et al. 1983), and shows that oikopleurid tunicates do not store neutral lipid as a long-term, overwintering energy reserve or in response to the bloom. Some pre-bloom specimens contained moderate levels of TAG (2 to $16 \%$ of total lipids; Fig. 3c), although betweenindividual variability was high. This low occurrence of storage lipids may indicate a population under nutritional stress (Clarke et al. 1987), or a rapidly growing population (Norrbin et al. 1990). The latter strategy would be consistent with our observations of active feeding of $O$. vanhoeffeni throughout the year (Urban et al. 1992), and somatic growth in the late spring and summer (Deibel 1988).

In summary, Oikopleura vanhoeffeni has a relatively low lipid content, on average ca $6.5 \%$ of dry weight. This is similar to the mean lipid content of a number of arctic, gelatinous 'carnivorous' zooplankton (Larson \& Harbison 1989). Triacylglycerol, the only storage lipid observed, occurred in only a few tunicates collected before the spring diatom bloom had begun. The predominant lipid class was phospholipids, indicating investment in cell membranes. Thus, although $O$. vanhoeffeni is a cold ocean, suspension-feeding zooplankter, it does not show the usual adaptation to pulsed food supplies shown by high-latitude copepods, i.e. storage of large quantities of wax esters and triacylglycerols. Rather, $O$. vanhoeffeni has the lipid characteristics of a gelatinous, opportunistic colonist, i.e. that of an omnivore, with the ability to direct ingested food energy into rapid somatic growth or gamete production.

Acknowledgements. The authors thank divers of the Ocean Sciences Centre for help with the collection of $O$. vanhoeffeni. Drs Ray Thompson and Chris Parrish commented on an earlier draft. This work was supported by an Operating Grant to D.D. from the Natural Sciences and Engineering Research Council of Canada. This paper is contribution number 166 from the Ocean Sciences Centre, Memorial University, and contribution number 805 from the Great Lakes Environmental Research Laboratory.

\section{LITERATURE CITED}

Clarke, A., Holmes, L. J., Hopkins, C. C. E. (1987). Lipid in an arctic food chain: Calanus, Bolinopsis, Beroe. Sarsia 72 : $41-48$

Davis, C. C. (1982). A preliminary quantitative study of the zooplankton from Conception Bay, Insular Newfoundland, Canada. Int. Rev. ges. Hydrobiol. 67: 713-747

Davis, C. C. (1986). A comparison of the zooplankton in two Newfoundland bays with differing influences from major currents. Int. Rev, ges. Hydrobiol. 71: 11-47

Deibel, D. (1986). Feeding mechanism and house of the appendicularian Oikopleura vanhoeffeni. Mar. Biol. 93: $429-436$

Deibel, D. (1988). Filter feeding by Oikopleura vanhoeffeni: grazing impact on suspended particles in cold ocean waters. Mar. Biol. 99: 177-186

Deibel, D., Tumer, J. T. (1985). Zooplankton feeding ecology: contents of fecal pellets of the appendicularian Oikopleura vanhoeffeni. Mar. Ecol. Prog. Ser. 27: 67-78

Falk-Petersen, S., Sargent, J. R., Tande, K.S. (1987). Lipid composition of zooplankton in relation to the sub-arctic food web. Polar Biol. 8: 115-120

Flood, P. R., Deibel, D., Morris, C. C. (1992). Filtration of colloidal melanin from sea water by planktonic tunicates. Nature 355: 630-632

Folch, J., Lees, M., Sloane Stanley, G. H. (1957). A simple method for the isolation and purification of total lipids from animal tissues. J. Biol. Chem. 226: 497-509

Gadomski, D. M., Boehlert, G. W. (1984). Feeding ecology of pelagic larvae of English sole Parophrys vetulus and butter sole Isopsetta isolepis off the Oregon coast. Mar. Ecol. Prog. Ser. 20: 1-12

Gardner, W S, Frez, W. A., Cichocki, E. A., Parrish, C. C. 
(1985) Micromethod for lipids in aquatic invertebrates. Limnol. Oceanogr 30: 1100-1105

Gatten, R. R., Sargent, J. R., Forsberg, T E. V., O'Hara, C. M., Corner, E. D. S. (1980). On the nutrition and metabolism of zooplankton XIV Utilization of lipid by Calanus helgolandicus during maturation and reproduction. J. mar. biol. Ass. U.K. 60: 391-399

Hargrave, B. T., von Bodungen, B., Conover, R. J., Fraser, A. J., Phillips, G., Vass, W. P. (1989). Seasonal changes in sedimentation of particulate matter and lipid content of zooplankton collected by sediment trap in the arctic ocean off Axel Heiberg Island. Polar Biol. 9: 467-475

Joseph, J. D. (1979). Lipid composition of marine and estuarine invertebrates: porifera and cnidaria. Prog. Lipid Res. 18: 1-30

Kattner, G., Krause, M. (1987). Changes in lipids during the development of Calanus finmarchicus s. l. from copepodid I to adult. Mar. Biol. 96: 511-518

Keats, D. W., Steele, D. H., South, G. R. (1987). Ocean pout (Macrozoarces americanus (Bloch and Schneider) (Pices: Zoarcidae)) predation on green sea urchins (Strongylocentrotus droebachiensis) (O. F. Mull.)) (Echinodermata: Echinoidea) in eastern Newfoundland. Can. J. Zool. 65 : 1515-1521

Knoechel, R., Steel-Flynn, D. (1989). Clearance rates of Oikopleura in cold coastal Newfoundland waters: a predictive model and its trophodynamic implications. Mar. Ecol. Prog. Ser. 53: 257-266

Larson, R. J., Harbison, G. R. (1989). Source and fate of lipids in polar gelatinous zooplankton. Arctic 42: 339-346

Lee, R. F. (1974). Lipids of zooplankton from Bute Inlet, British Columbia. J. Fish. Res. Bd Can, 31: 1577-1582

Lee, R. F. (1975). Lipids of arctic zooplankton. Comp. Biochem Physiol. 51B: 263-266

Lee, R. F., Nevenzel, J. C., Paffenhöfer, G.-A. (1972). The presence of wax esters in marine planktonic copepods. Naturwissenschaften 59: 406-411

Madin, L. P., Cetta, C. M., McAlister, V L. (1981). Elemental and biochemical composition of salps (Tunicata Thaliacea). Mar. Biol. 63: 217-226

Mahoney, E. M., Buggeln, R. G. (1983). Seasonal variations in the concentration of Oikopleura spp. (Tunicata: Appendicularial in Conception Bay, Newfoundland. Can. Tech. Rep. Fish. Aquat. Sci. 1155
Morris, R. J., McCartney, M. J., Schulze-Röbbecke, A. (1983) Bolinopsis infundibulum (O. F. Müller): biochemical composition in relation to diet. J exp mar Biol. Ecol. 67 . 149-157

Napolitano, G. E., MacDonald, B. A., Thompson, R. J., Ackman, R. G. (1992). Lipid composition of eggs and adductor muscle in giant scallops (Placopecten magellanicus Gmelin) from different habitats. Mar. Biol. 113: 71-76

Norrbin, M. F., Olsen, R.-E., Tande, K. S. (1990). Seasonal variation in lipid class and fatty acid composition of two small copepods in Balsfjorden, northern Norway. Mar Biol. 105: 205-211

Parrish, C. C. (1986). Dissolved and particulate lipid classes in the aquatic environment. Ph.D. thesis, Dalhousie Univ.

Parrish. C. C. (1987). Separation of aquatic lipid classes by chromarod thin-layer chromatography with measurement by Iatroscan flame ionization detection. Can. J. Fish. Aquat. Sci. 44: 722-731

Parrish, C. C., Zhou, X., Herche, L. R. (1988). Flame ionization and flame thermionic detection of carbon and nitrogen in aquatic lipid and humic-type classes with an latroscan Mark IV. J. Chromatogr. 435: 350-356

Schneider, G. (1989). Carbon and nitrogen content of marine zooplankton dry material; a short review. Plankton News 11: $4-7$

Shelbourne, J. E. (1962). A predator-prey size relationship for plaice larvae feeding on Oikopleura. J. mar. biol. Ass. U.K. 42: 243-252

Shiga, N. (1976). Maturity stages and relative growth of Oikopleura labradoriensis Lohmann (Tunicata, Appendicularia). Bull. Plankton Soc. Japan. 23: 81-95

Smith, S. L. (1990). Egg production and feeding by copepods prior to the spring bloom of phytoplankton in Fram Strait, Greenland Sea. Mar. Biol. 106: 59-69

Tande, K. S., Henderson, R. J. (1988). Lipid composition of copepodite stages and adult females of Calanus glacialis in arctic waters of the Barents Sea. Polar Biol. 8: 333-339

Urban, J., McKenzie, C. H., Deibel, D. (1992). Seasonal differences in the content of Oikopleura vanhoeffeni and Calanus finmarchicus faecal pellets: implications for food web dynamics in coastal Newfoundland waters. Mar. Ecol. Prog. Ser. in press

Manuscript first received: June 2, 1992

Revised version accepted: September 28, 1992 